\title{
Males and females gonad fatty acids of the sea urchins Paracentrotus lividus and Arbacia lixula (Echinodermata)
}

\author{
Inés Martínez-Pita · Francisco J. García • \\ María-Luisa Pita
}

Received: 25 May 2009 / Revised: 18 September 2009 / Accepted: 24 September 2009 / Published online: 15 October 2009

(C) Springer-Verlag and AWI 2009

\begin{abstract}
The aim of this study was to analyze male and female gonad fatty acids of two sea urchin species, Paracentrotus lividus and Arbacia lixula, from the south coast of Spain. Additionally, we investigated possible differences between two locations. The ovaries of both species showed higher percentages of 14:0, 16:0, 16:1n-7, 18:2n-6, 18:3n-3 and 18:4n-3 than testes and lower levels of 18:0, 22:1n-9, 20:4n-6 and 22:5n-3. In P. lividus but not in A. lixula, the level of 20:5n-3 was higher in testes than in ovaries. These differences between sexes probably indicate different requirements of males and females during gametogenesis although the presence of a large number of gametes in the mature gonad may also have influences on fatty acid composition. Significant differences in gonad fatty acid profiles where also found when individuals of $P$. lividus collected at a location of the Mediterranean region were compared with specimens collected at the Atlantic coast. The most remarkable changes were the lower levels of 14:0, 18:1n-7, 20:1n-9, 20:4n-6 and 22:4n-6 and the higher values of 20:1n-11,
\end{abstract}

Communicated by H.-D. Franke.

I. Martínez-Pita $(\square)$

I.F.A.P.A. Centro "Agua del Pino",

Consejería de Agricultura y Pesca,

Carretera Punta Umbría-Cartaya km 3.8, Huelva, Spain

e-mail: ines.martinez@juntadeandalucia.es

F. J. García

Departamento de Sistemas Físicos,

Químicos y Naturales. Facultad de Ciencias Experimentales, Universidad Pablo de Olavide, Carretera de Utrera Km1,

Sevilla, Spain

\section{M.-L. Pita}

Departamento de Bioquímica Médica y Biología Molecular, Universidad de Sevilla, Avda Sánchez Pizjúan 7,

41009 Sevilla, Spain 20:5n-3 and 22:6n-3 found in males and females of the Mediterranean specimens compared to those of the Atlantic coast. These differences probably reflect the differences in potential food sources at each location.

Keywords Fatty acids $\cdot$ Sea urchin $\cdot$ Males $\cdot$ Females · Gonad

\section{Introduction}

Paracentrotus lividus (Lamarck, 1816) and Arbacia lixula (Linnaeus, 1758) are two sea urchin species that coexist on hard substrata in shallow subtidal habitats of the Mediterranean and Atlantic coasts of Spain. Paracentrotus lividus is an opportunistic generalist species able to exploit a number of food sources, although brown macroalgae and seagrasses constitute the main feeding resource (Boudouresque and Verlaque 2007; Privitera et al. 2008). Arbacia lixula, however, shows a strong preference for encrusting corallines (Frantzis et al. 1988; Privitera et al. 2008). It has been reported that the quality and quantity of food affects the reproductive maturation and growth of sea urchins (Fernández and Pergent 1998; Meidel and Scheibling 1999), and that they also modify the biochemical composition of gonads (Hammer et al. 2006; Fernández 1997; LiyanaPathirana and Shahidi 2002a). Fatty acids are also important for sea urchin reproduction. During gametogenesis, they can be used as a source of energy (Marsh and Watts 2001) and, additionally, sea urchin spermatozoa obtain energy for swimming through oxidation of fatty acids derived either from phosphatidylcholine or from triglycerides (Mita and Nakamura 2001). In the eggs, triglycerides are important for larval development and survival (Kozhina et al. 1978; Sewell 2005; Yasumasu et al. 1984). Sea 
urchins as many other marine animals are able to synthesize most fatty acids but dietary lipids also provide the essential fatty acids linoleic (18:2n-6) and $\alpha$-linolenic (18:3n-3) and some other important long-chain n- 6 and $n-3$ polyunsaturated fatty acids such as arachidonic (20:4n-6) and eicosapentaenoic (20:5n-3) acids. Thus, tissue fatty acid composition must be considered as the result of endogenous synthesis and exogenous supply.

In this study, the first objective has been to investigate sex differences in the gonad fatty acids of two sea urchin species, Paracentrotus lividus and Arbacia lixula from the south coast of Spain. Additionally, the possible influence of the habitat was analyzed comparing specimens of $P$. lividus collected at two different shores.

\section{Materials and methods}

The study was conducted at two locations on the south shore of Spain, La Herradura (Granada, Mediterranean Sea) on the southeastern coast $\left(3^{\circ} 45^{\prime} 29^{\prime \prime} \mathrm{W} 36^{\circ} 44^{\prime} 14^{\prime \prime} \mathrm{N}\right)$, and Torregorda (Cadiz, Atlantic Ocean) on the southwestern side $\left(6^{\circ} 15^{\prime} 0^{\prime \prime} \mathrm{W} 36^{\circ} 28^{\prime} 1^{\prime \prime} \mathrm{N}\right)$ (Fig. 1). Specimens of Paracentrotus lividus were collected at each of these two locations, whereas Arbacia lixula was only collected at La Herradura since this species is not present at Torregorda. The sampling station of La Herradura, located at depths between 3 and $7 \mathrm{~m}$, has vertical walls and large rocks lying on a soft bottom with sandy and pebbly patches. It is a sheltered area, exposed to low hydrodynamism. The studied assemblages are dominated by seaweed, mainly the articulated red algae Corallina elongate J. Ellis \& Solander 1786, some encrusting coralline algae as those of the genera Lithophyllum Philippi 1837 and Mesophyllum Lemoine 1928, and some frondose brown and red algae as Cystoseira sp.C. Agardh 1820, Stypocaulon scoparium (Linnaeus) Kützing 1843, Padina pavonica (Linnaeus) Thivy 1960, Sphacelaria sp. Lyngbye 1819, Colpomenia sinuosa (Mertens

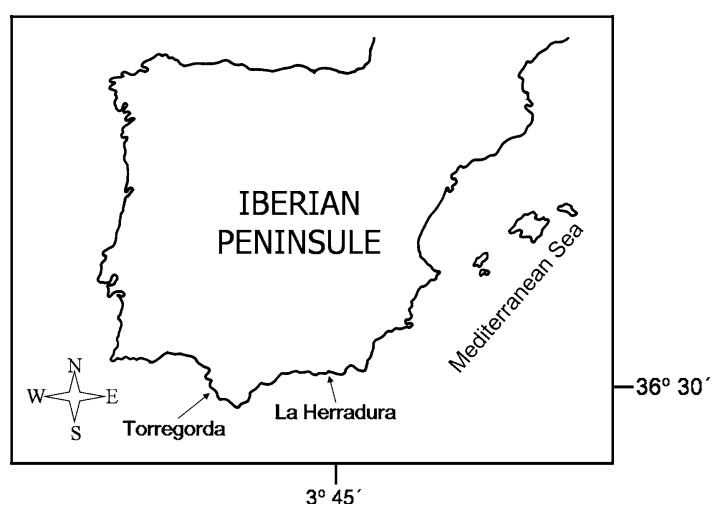

Fig. 1 Map showing the sampling sites in the south of Spain ex Roth, 1806) Drebès \& Solier 1851 and Asparagopsis armata Harvey 1855. Torregorda is an intertidal area where the bottom is a horizontal rocky platform with many pools. It is exposed to high hydrodynamism. With respect to the seaweed structure, there is a community of red turfing algae as those of the genera Gelidium Lamouroux, 1813, Caulacanthus Kützing 1843 and Corallina Linnaeus 1758, some brown algae as Dictyota dichotoma (Hudson) J.V. Lamouroux 1809 and Dictyota fasciola (Roth) J.V. Lamouroux 1809, and some species of the green algae Ulva Linnaeus 1753. The sea urchins were found on the walls of the pools. The differences in water temperature between both locations are small (mean value of the year: La Herradura: $18.58 \pm 4.38$; Torregorda: $18.67 \pm 3.50$ ).

The individuals of each sea urchin species were collected and brought to the laboratory where they were dissected, and their gonads were removed. Two gonads were stored at $-30^{\circ} \mathrm{C}$ for fatty acid analysis, and the remainder was fixed in formaldehyde $10 \%$ for microscopic determination of sex.

Sampling was carried out from January to May in 2003, since previous studies in their reproductive biological cycle (Martínez et al. 2003; Sánchez-España et al. 2004) and personal observations have showed that this is the maturing season. A total of 37 males and 30 females of A. lixula collected at La Herradura, 51 males and 15 females of $P$. lividus collected at La Herradura and 42 males and 29 females of $P$. lividus from Torregorda were analyzed. As there were no changes in fatty acid composition in the sampling period (January-May 2003, results not shown) for the statistical analysis, the results were pooled for sex and location.

Fatty acid analysis

For each individual, one gonad was weighed and homogenized in $0.9 \% \mathrm{NaCl}(1: 2 \mathrm{w} / \mathrm{v})$. The fatty acid methyl esters were prepared by a direct transesterification reaction according to Lepage and Roy (1987). Briefly, $2 \mathrm{~mL}$ of methanol-benzene $4: 1(\mathrm{v} / \mathrm{v})$ was added to $0.2 \mathrm{~mL}$ of homogenate and then, while stirring, $0.2 \mathrm{~mL}$ of acetyl chloride was slowly added. Tubes were tightly closed and maintained at $100^{\circ} \mathrm{C}$ for $1 \mathrm{~h}$. After cooling, $5 \mathrm{~mL}$ of $6 \% \mathrm{~K}_{2} \mathrm{CO}_{3}$ solution was added. The tubes were then shaken and centrifuged, and the benzene upper phase was recovered for fatty acid analysis.

Fatty acid methyl esters were separated by gas-liquid chromatography using a Hewlett-Packard 5890 gas chromatograph equipped with a fused silica capillary column (30 $\mathrm{m} \times 0.25 \mathrm{~mm}$ ID) coated with TR-WAX and supplied by Teknokroma (Barcelona, Spain). The initial column temperature was $190^{\circ} \mathrm{C}$, with an initial hold time of $10 \mathrm{~min}$, and was programmed to $240^{\circ} \mathrm{C}$ at a rate of $2^{\circ} \mathrm{C} / \mathrm{min}$ and a final hold time $10 \mathrm{~min}$. The temperature of the injector was 
$250^{\circ} \mathrm{C}$ and that of the detector was $275^{\circ} \mathrm{C}$. Peaks were identified by comparison with known standards (FAME mix C4-C24, Supelco/Sigma-Aldrich) and with a well-characterized profile of menhaden fish oil (Supelco-SigmaAldrich). The identification of non-methylene-interrupted dienoic fatty acids was based upon the work of Takagi et al. (1986), since these compounds do not appear either in the FAME mix or in menhaden oil. The results were reported as area percentages.

\section{Statistical methods}

Values were expressed as mean percentages $\pm \mathrm{SD}$. Unpaired Student $t$-test was used to determine differences between male and female gonad fatty acids of both P. livi$d u s$ and A. lixula. This test was also used to analyze differences between males or females of $P$. lividus sampled at the locations of La Herradura and Torregorda.

\section{Results}

Male and female gonad fatty acids of A. lixula and $P$. livi$d u s$ are shown in Tables 1,2 and 3. A similar pattern was found for males and females irrespective of the considered sea urchin species or the sampling location. In both ovaries and testes, the three major saturated fatty acids were myristic (14:0), palmitic (16:0) and stearic (18:0) although their levels, especially those of 14:0 and 18:0, differed in P. lividus with respect to A. lixula. Higher percentages of 14:0 and 16:0 and lower levels of 18:0 were found in ovaries when compared to testes; these differences were more marked in A. lixula, especially for 18:0 whose level in males doubled that found in females. A total of seven monounsaturated fatty acids (MUFA) were identified in the gonads of the two sea urchins species: 16:1n-7, 18:1n-7, 18:1n-9, 20:1n-7, 20:1n-9, 20:1n-11 and 22:1n-9. The major MUFA was 20:1n-11 with values that varied between 5 and $7 \%$, whereas the two minor MUFA were 18:1n-9 and 20:1n-7 whose levels did not reach 2\%. In $A$. lixula, the percentage of 20:1n-9 was very low and hardly exceeded $1 \%$ whereas in P. lividus it was approximately $4 \%$. The most important differences observed in MUFA between males and females were the higher level of $16: 1 \mathrm{n}$ 7 and the lower percentage of 22:1n-9 found in the ovaries comparing to testes. In A. lixula, 18:1n-7 and 20:1n-9 were also significantly elevated in the gonads of females.

As shown in Tables 1, 2 and 3, in both ovaries and testes, the two major polyunsaturated fatty acids (PUFA) were arachidonic (20:4n-6) (10-17\%) and eicosapentaenoic $(20: 5 n-3)(13-17 \%)$ acids. The percentage of $20: 4 n-6$ and $22: 5 n-3$ were higher in males than in females, whereas the two essential fatty acids $18: 2 n 6,18: 3 n-3$ as well as $18: 4 n-3$
Table 1 Gonad fatty acid composition of Arbacia lixula males and females collected at La Herradura

\begin{tabular}{|c|c|c|}
\hline Fatty acids & $\begin{array}{l}\text { Males } \\
(n=37)\end{array}$ & $\begin{array}{l}\text { Females } \\
(n=30)\end{array}$ \\
\hline $14: 0$ & $2.0 \pm 1.1$ & $3.1 \pm 0.9^{\mathrm{a}}$ \\
\hline $15: 0$ & $1.2 \pm 0.4$ & $1.6 \pm 0.4^{\mathrm{a}}$ \\
\hline 16:0 DMA & $0.8 \pm 0.3$ & $0.8 \pm 0.5$ \\
\hline $16: 0$ & $15.0 \pm 1.6$ & $17.4 \pm 2.1^{\mathrm{a}}$ \\
\hline $17: 0$ & $0.8 \pm 0.1$ & $0.7 \pm 0.2^{\mathrm{a}}$ \\
\hline 18:0 DMA & $4.0 \pm 1.3$ & $3.7 \pm 1.1$ \\
\hline 18:0 & $7.1 \pm 1.8$ & $4.2 \pm 1.4^{\mathrm{a}}$ \\
\hline 20:0 & $1.7 \pm 0.5$ & $1.3 \pm 0.4^{\mathrm{a}}$ \\
\hline$\sum$ saturated & $27.9 \pm 2.0$ & $28.2 \pm 2.6$ \\
\hline $16: 1 n-7$ & $1.4 \pm 0.9$ & $3.0 \pm 1.2^{\mathrm{a}}$ \\
\hline $18: 1 n-9$ & $1.1 \pm 0.7$ & $1.3 \pm 0.4$ \\
\hline $18: 1 n-7$ & $3.0 \pm 0.7$ & $3.7 \pm 0.7^{\mathrm{a}}$ \\
\hline $20: 1 n-11$ & $6.8 \pm 2.7$ & $6.7 \pm 1.8$ \\
\hline $20: 1 n-9$ & $1.1 \pm 0.4$ & $1.4 \pm 0.4^{\mathrm{a}}$ \\
\hline $20: 1 n-7$ & $1.3 \pm 0.4$ & $1.2 \pm 0.3$ \\
\hline $22: 1 n-9$ & $4.5 \pm 1.2$ & $2.6 \pm 1.1^{\mathrm{a}}$ \\
\hline$\sum$ monoenoic & $19.3 \pm 3.2$ & $19.8 \pm 1.2$ \\
\hline $18: 2 n-6$ & $0.5 \pm 0.3$ & $0.9 \pm 0.4^{\mathrm{a}}$ \\
\hline $18: 3 n-6$ & $1.2 \pm 0.2$ & $1.0 \pm 0.2^{\mathrm{a}}$ \\
\hline $20: 2 n-6$ & $1.9 \pm 0.5$ & $1.9 \pm 0.4$ \\
\hline $20: 3 n-6$ & $0.4 \pm 0.1$ & $0.4 \pm 0.1$ \\
\hline $20: 4 n-6$ & $16.9 \pm 2.8$ & $13.8 \pm 2.5^{\mathrm{a}}$ \\
\hline $22: 4 n-6$ & $1.8 \pm 0.2$ & $1.6 \pm 0.3$ \\
\hline $22: 5 n-6$ & $0.8 \pm 0.4$ & $0.7 \pm 0.4$ \\
\hline$\sum$ PUFA n-6 & $21.7 \pm 2.9$ & $18.6 \pm 2.8^{\mathrm{a}}$ \\
\hline $18: 3 n-3$ & $0.6 \pm 0.5$ & $1.1 \pm 0.5^{\mathrm{a}}$ \\
\hline $18: 4 n-3$ & $1.2 \pm 0.5$ & $1.9 \pm 0.5^{\mathrm{a}}$ \\
\hline $20: 3 n-3$ & $1.2 \pm 0.5$ & $1.2 \pm 0.3$ \\
\hline $20: 4 n-3$ & $0.2 \pm 0.1$ & $0.3 \pm 0.1^{\mathrm{a}}$ \\
\hline $20: 5 n-3$ & $15.5 \pm 5.0$ & $16.3 \pm 4.2$ \\
\hline $22: 5 n-3$ & $0.9 \pm 0.3$ & $0.7 \pm 0.2^{\mathrm{a}}$ \\
\hline $22: 6 n-3$ & $1.8 \pm 0.8$ & $1.9 \pm 1.4$ \\
\hline$\sum$ PUFA n-3 & $21.4 \pm 5.7$ & $23.5 \pm 4.6$ \\
\hline $20: 2 \Delta 5,11$ NMID & $2.7 \pm 0.8$ & $3.1 \pm 0.7^{\mathrm{a}}$ \\
\hline $20: 2 \Delta 5,13$ NMID & $0.4 \pm 0.3$ & $0.6 \pm 0.3^{\mathrm{a}}$ \\
\hline
\end{tabular}

Values are mean percentages $\pm \mathrm{SD}$

$n$ Number of samples, DMA dimethylacetal, NMID non-methyleneinterrupted diene, PUFA polyunsaturated fatty acids

a $P<0.05$ with respect to males

showed higher levels in females. Eicosapentaenoic acid did not show significant differences between males and females; although, while in A. lixula, this fatty acid was slightly higher in females than in males, in $P$. lividus the opposite was observed. In addition to these n-3 and n-6 PUFA, two non-methylene-interrupted dienoic fatty acids 
Table 2 Gonad fatty acid composition of Paracentrotus lividus males and females collected at La Herradura

\begin{tabular}{|c|c|c|}
\hline Fatty acids & $\begin{array}{l}\text { Males } \\
(n=51)\end{array}$ & $\begin{array}{l}\text { Females } \\
(n=15)\end{array}$ \\
\hline $14: 0$ & $7.3 \pm 2.0$ & $8.5 \pm 1.2^{\mathrm{a}}$ \\
\hline $15: 0$ & $1.1 \pm 0.2$ & $1.2 \pm 0.2^{\mathrm{a}}$ \\
\hline 16:0 DMA & $0.3 \pm 0.1$ & $0.2 \pm 0.1^{\mathrm{a}}$ \\
\hline $16: 0$ & $16.9 \pm 2.7$ & $17.9 \pm 1.9$ \\
\hline $17: 0$ & $0.4 \pm 0.1$ & $0.4 \pm 0.1$ \\
\hline 18:0 DMA & $3.9 \pm 1.1$ & $3.3 \pm 0.9$ \\
\hline $18: 0$ & $3.6 \pm 0.7$ & $3.1 \pm 0.5^{\mathrm{a}}$ \\
\hline $20: 0$ & $0.6 \pm 0.1$ & $0.6 \pm 0.1$ \\
\hline$\sum$ saturated & $29.9 \pm 4.3$ & $31.7 \pm 2.5$ \\
\hline $16: 1 n-7$ & $2.2 \pm 1.0$ & $2.9 \pm 0.7^{\mathrm{a}}$ \\
\hline $18: \ln -9$ & $1.4 \pm 0.6$ & $1.6 \pm 0.4$ \\
\hline $18: 1 n-7$ & $2.6 \pm 0.4$ & $2.7 \pm 0.3$ \\
\hline $20: 1 n-7$ & $1.2 \pm 0.4$ & $0.9 \pm 0.2^{\mathrm{a}}$ \\
\hline $20: 1 n-9$ & $4.3 \pm 0.9$ & $3.6 \pm 0.6^{\mathrm{a}}$ \\
\hline $20: 1 n-11$ & $5.7 \pm 1.0$ & $5.6 \pm 1.2$ \\
\hline $22: 1 n-9$ & $4.3 \pm 0.9$ & $3.5 \pm 0.5^{\mathrm{a}}$ \\
\hline$\sum$ monoenoic & $21.6 \pm 1.8$ & $20.9 \pm 1.0$ \\
\hline $18: 2 n-6$ & $0.8 \pm 0.4$ & $1.2 \pm 0.3^{\mathrm{a}}$ \\
\hline $18: 3 n-6$ & $0.6 \pm 0.1$ & $0.6 \pm 0.1$ \\
\hline $20: 2 n-6$ & $2.0 \pm 0.7$ & $1.7 \pm 0.3$ \\
\hline $20: 3 n-6$ & $0.4 \pm 0.1$ & $0.5 \pm 0.1$ \\
\hline $20: 4 n-6$ & $10.8 \pm 2.4$ & $10.1 \pm 1.3$ \\
\hline $22: 4 n-6$ & $1.6 \pm 0.3$ & $1.5 \pm 0.2$ \\
\hline$\sum$ PUFA n-6 & $16.2 \pm 2.9$ & $15.6 \pm 1.5$ \\
\hline $18: 3 n-3$ & $1.1 \pm 0.4$ & $1.6 \pm 0.3^{\mathrm{a}}$ \\
\hline $18: 4 n-3$ & $1.2 \pm 0.6$ & $1.8 \pm 0.4^{\mathrm{a}}$ \\
\hline $20: 3 n-3$ & $1.4 \pm 0.4$ & $1.4 \pm 0.3$ \\
\hline $20: 4 n-3$ & $0.4 \pm 0.1$ & $0.5 \pm 0.1$ \\
\hline $20: 5 n-3$ & $17.5 \pm 3.2$ & $16.5 \pm 1.8$ \\
\hline $22: 5 n-3$ & $0.7 \pm 0.3$ & $0.5 \pm 0.1^{\mathrm{a}}$ \\
\hline $22: 6 n-3$ & $1.0 \pm 0.4$ & $0.9 \pm 0.3$ \\
\hline$\sum$ PUFA n-3 & $23.4 \pm 3.0$ & $23.1 \pm 2.0$ \\
\hline 20:2 5,11 NMID & $4.0 \pm 1.2$ & $4.2 \pm 0.6$ \\
\hline 20:2 5,13 NMID & $0.8 \pm 0.2$ & $0.9 \pm 0.1$ \\
\hline
\end{tabular}

Values are mean percentages $\pm \mathrm{SD}$

$n$ Number of samples, DMA dimethylacetal, NMID non-methyleneinterrupted diene, $P U F A$ polyunsaturated fatty acids

a $P<0.05$ with respect to males

(NMID), 20:2 $\Delta 5,11$ and 20:2 $\Delta 5,13$, were identified in the gonads of the two sea urchins species. Their values tended to be lower in males than in females, and in A. lixula, these differences were more marked and statistically significant.

As described earlier, specimens from both locations showed similar differences in gonad fatty acids between males and females but, additionally, some significant
Table 3 Gonad fatty acid composition of Paracentrotus lividus males and females collected at Torregorda

\begin{tabular}{|c|c|c|}
\hline Fatty acids & $\begin{array}{l}\text { Males } \\
(n=41)\end{array}$ & $\begin{array}{l}\text { Females } \\
(n=29)\end{array}$ \\
\hline $14: 0$ & $7.8 \pm 2.1$ & $8.9 \pm 1.5^{\mathrm{a}}$ \\
\hline $15: 0$ & $0.9 \pm 0.2$ & $1.1 \pm 0.3$ \\
\hline 16:0 DMA & $0.3 \pm 0.1$ & $0.2 \pm 0.1^{\mathrm{a}}$ \\
\hline $16: 0$ & $16.9 \pm 2.6$ & $18.2 \pm 2.1^{\mathrm{a}}$ \\
\hline $17: 0$ & $0.4 \pm 0.1$ & $0.4 \pm 0.1$ \\
\hline 18:0 DMA & $4.3 \pm 1.5$ & $3.5 \pm 1.2^{\mathrm{a}}$ \\
\hline $18: 0$ & $3.7 \pm 0.8$ & $3.3 \pm 0.5^{\mathrm{a}}$ \\
\hline $20: 0$ & $0.6 \pm 0.2$ & $0.6 \pm 0.1$ \\
\hline$\sum$ saturated & $30.4 \pm 3.9$ & $32.5 \pm 3.2^{\mathrm{a}}$ \\
\hline $16: 1 n-7$ & $2.1 \pm 1.1$ & $2.5 \pm 0.8$ \\
\hline $18: 1 n-9$ & $1.4 \pm 0.6$ & $1.6 \pm 0.4$ \\
\hline $18: 1 n-7$ & $2.9 \pm 0.6$ & $3.1 \pm 0.5$ \\
\hline $20: 1 n-11$ & $5.1 \pm 1.4$ & $4.8 \pm 1.3$ \\
\hline $20: 1 n-9$ & $4.8 \pm 1.0$ & $5.0 \pm 1.2$ \\
\hline $20: 1 n-7$ & $1.0 \pm 0.4$ & $0.9 \pm 0.2$ \\
\hline $22: 1 n-9$ & $4.3 \pm 1.2$ & $3.7 \pm 0.9^{\mathrm{a}}$ \\
\hline$\sum$ monoenoic & $21.6 \pm 2.5$ & $21.6 \pm 1.5$ \\
\hline $18: 2 n-6$ & $0.9 \pm 0.4$ & $1.1 \pm 0.4^{\mathrm{a}}$ \\
\hline $18: 3 n-6$ & $0.7 \pm 0.1$ & $0.6 \pm 0.1$ \\
\hline $20: 2 n-6$ & $2.0 \pm 0.5$ & $1.8 \pm 0.4$ \\
\hline $20: 3 n-6$ & $0.6 \pm 0.1$ & $0.7 \pm 0.2$ \\
\hline $20: 4 n-6$ & $12.3 \pm 1.8$ & $11.3 \pm 1.9^{\mathrm{a}}$ \\
\hline $22: 4 n-6$ & $1.9 \pm 0.4$ & $2.1 \pm 0.5$ \\
\hline$\sum$ PUFA n-6 & $18.4 \pm 2.2$ & $17.6 \pm 2.4$ \\
\hline $18: 3 n-3$ & $1.2 \pm 0.6$ & $1.5 \pm 0.6$ \\
\hline $18: 4 n-3$ & $1.4 \pm 0.7$ & $1.7 \pm 0.5$ \\
\hline $20: 3 n-3$ & $1.1 \pm 0.3$ & $1.1 \pm 0.3$ \\
\hline $20: 4 n-3$ & $0.5 \pm 0.2$ & $0.5 \pm 0.2$ \\
\hline $20: 5 n-3$ & $14.6 \pm 4.3$ & $13.4 \pm 3.4$ \\
\hline $22: 5 n-3$ & $0.5 \pm 0.3$ & $0.4 \pm 0.2$ \\
\hline $22: 6 n-3$ & $0.8 \pm 0.4$ & $0.7 \pm 0.2$ \\
\hline$\sum$ PUFA n-3 & $20.2 \pm 3.7$ & $19.4 \pm 3.0$ \\
\hline 20:2 5,11 NMID & $4.1 \pm 1.1$ & $4.4 \pm 1.0$ \\
\hline 20:2 5,13 NMID & $0.7 \pm 0.2$ & $0.7 \pm 0.2$ \\
\hline
\end{tabular}

Values are mean percentages $\pm \mathrm{SD}$

$n$ Number of samples, DMA dimethylacetal, NMID non-methyleneinterrupted diene, $P U F A$ polyunsaturated fatty acids

a $P<0.05$ with respect to males

differences were found in gonad fatty acid profiles when individuals from different sites but with the same sex were compared. As shown in Figs. 2 and 3, the most important changes observed were the lower levels of 14:0, 18:1n-7, 20:1n-9, 20:4n-6 and 22:4n-6 and the higher values of $20: 1 n-11,20: 5 n-3$ and 22:6n-3 found in the gonads of both sexes of the specimens from La Herradura when compared 
Fig. 2 Statistical differences of gonads of Paracentrotus lividus from two different locations.

Number of samples at La Herradura: 51. Number of samples at Torregorda: 42. Values are means \pm SD SAT: total saturated fatty acids. MUFA: total monounsaturated fatty acids. PUFAn-6: total polyunsaturated fatty acids of n-6 series. PUFAn3: total polyunsaturated fatty acids of $\mathrm{n}-3$ series. $* P<0.05$ with respect to specimens collected at La Herradura selected fatty acids in the male

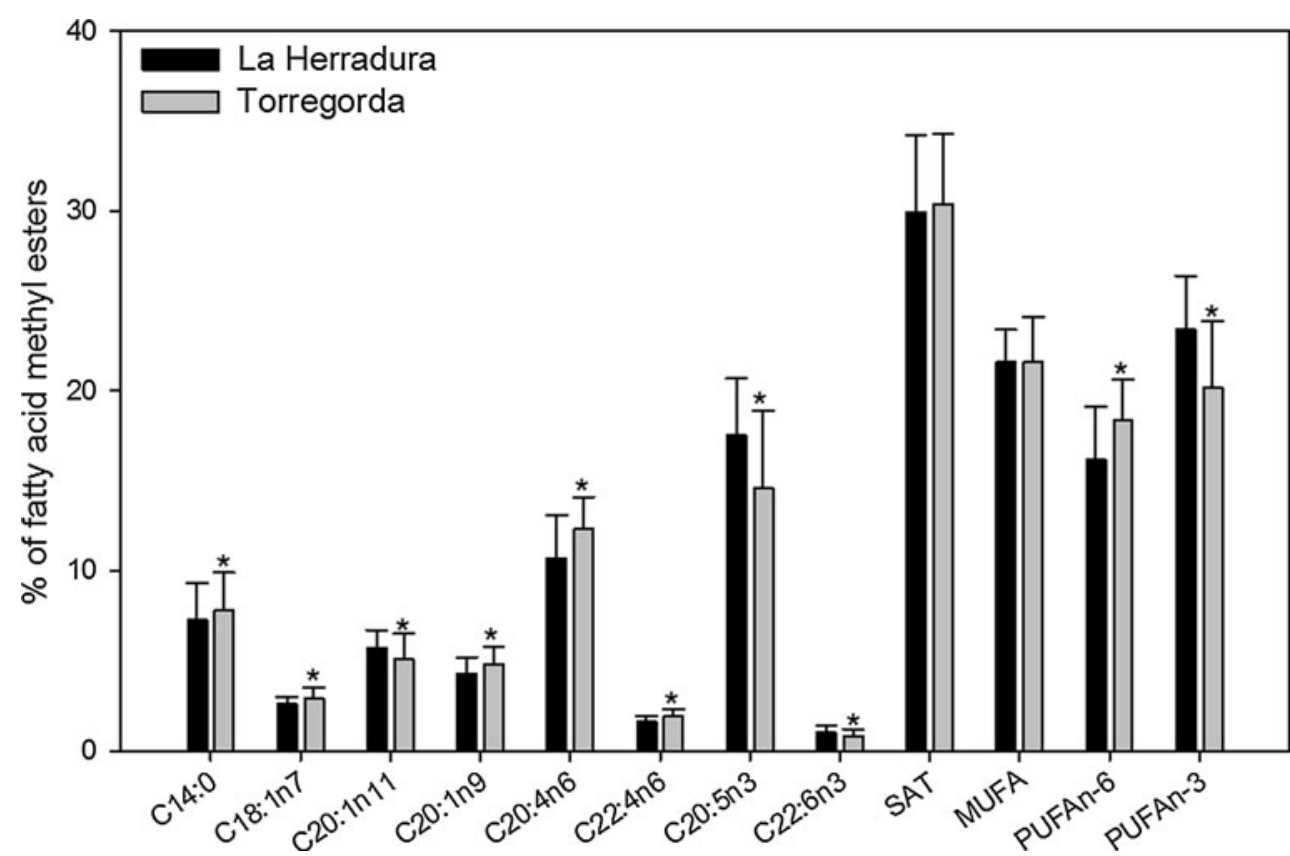

Fig. 3 Statistical differences of selected fatty acids in the female gonads of Paracentrotus lividus from two different locations.

Number of samples at La Herradura: 15. Number of samples at Torregorda: 29. Values are means \pm SD SAT: total saturated fatty acids. MUFA: total monounsaturated fatty acids. PUFAn-6: total polyunsaturated fatty acids of n-6 series. PUFAn-3: total polyunsaturated fatty acids of n- 3 series. $* P<0.05$ with respect to specimens collected at La Herradura

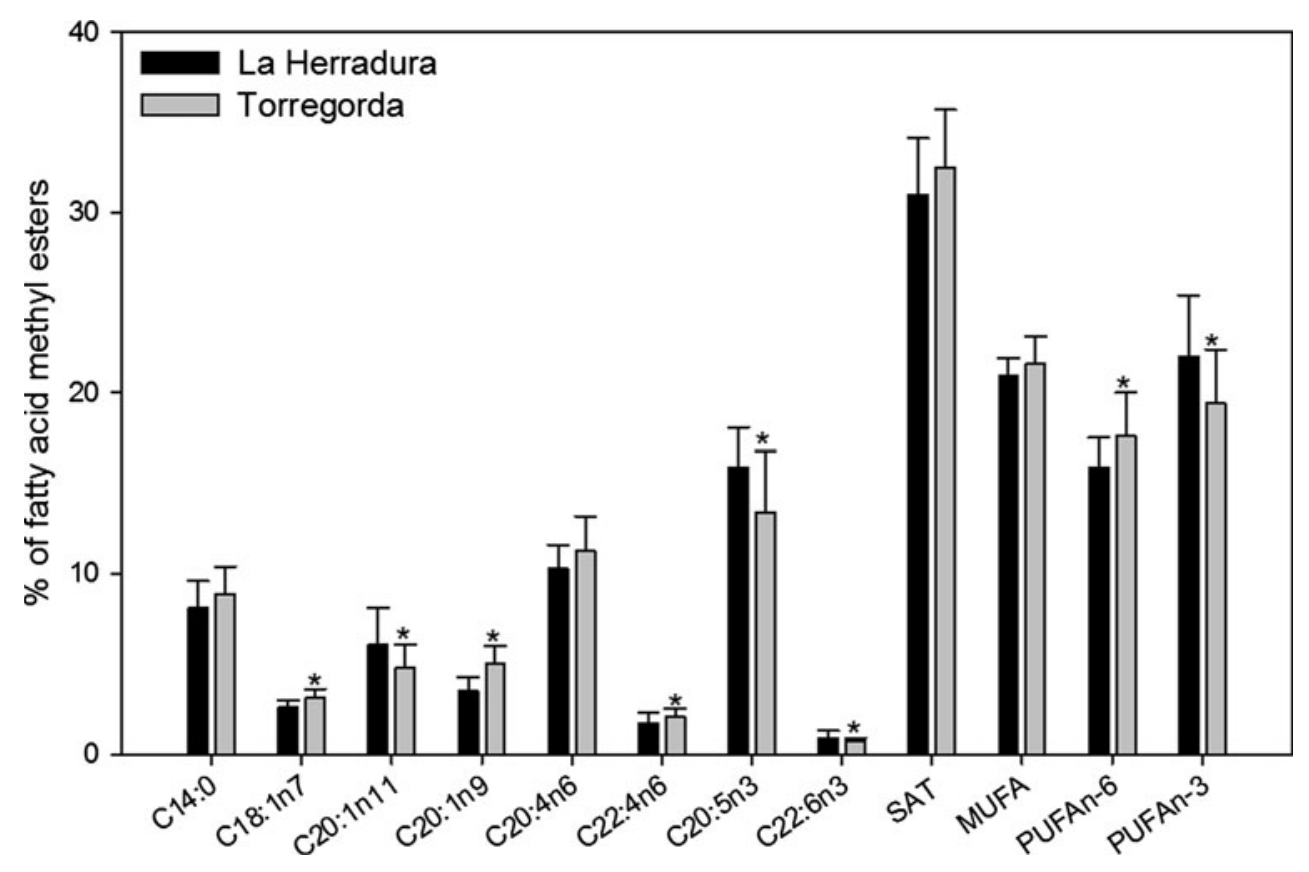

to those from Torregorda. The remaining fatty acids showed either no modifications or minor changes.

\section{Discussion}

Previous studies in marine invertebrates have reported significant differences in fatty acid composition between males and females. For example, it has been described that the female gonads of the molluscs Patella depressa (Pennant, 1777), Argopecten purpuratus (Lamarck, 1819), Haliotis rubra (Leach, 1814) and Haliotis laevigata (Donovan
1808) have higher levels of 14:0, 16:1n-7, 18:1n-9, 18:2n-6 and 18:3n-3 than the male gonads (Caers et al. 1999; Grubert et al. 2004; Morais et al. 2003). The level of 20:4n-6 is usually similar in males and females but the content of 20:5n-3 differs among species and, for example, is higher in the testes of $P$. depressa and $H$. rubra but lower in those of A. purpuratus (Caers et al., 1999; Grubert et al. 2004; Morais et al. 2003). In several species of Caprellidea, we have also reported higher percentages of 16:1n-7 and lower levels of $18: 0,20: 4 n-6$ and $20: 5 n-3$ in females than in males (Guerra-García et al. 2004). Sex differences in fatty acid composition of sea urchin gonads have only been 
reported for Psammechinus miliaris (Gmelin, 1178) by Hughes et al. (2005, 2006). These authors found higher proportions of 14:0, 16:1n-7 and 18:4n-3 in females as well as higher levels of 18:0, 20:4n-6, 20:5n-3 and 22:6n-3 in males. In the present study, we observed some degree of concordance with data obtained in P. miliaris, since the females of both $P$. lividus (either collected at La Herradura or at Torregorda) and A. lixula also showed higher percentages of 14:0, 16:1n-7 and 18:4n-3 and lower proportions of 18:0 and 20:4n-6. However, 20:5n-3 was elevated in the males of $P$. lividus but not in A. lixula where this fatty acid even tended to be higher in females; and in both sea urchin species 22:6n-3 did not differ between males and females. Additionally, the saturated 16:0 and the essential fatty acids $18: 2 n-6$ and $18: 3 n-3$ were higher in females, whereas 22:1n-9 and 22:5n-3 were higher in males.

Differences in fatty acid composition between male and female gonads may reflect metabolic particularities of gonad tissue related to specific requirements for spermatogenesis and oogenesis. In echinoderms, it has been reported that the reproductive effort is greater in females than in males and that the lipid and carbohydrate content is higher in ovaries than in testes (Fenaux et al. 1977; Raymond et al. 2007; Unuma et al. 2003). In addition, with increasing maturity stage, gonads are enriched with spermatozoa and oocytes whose different lipid composition could influence the gonad fatty acid composition. Hughes et al. (2006) studied the changes in gonad fatty acid profile of P. milliaris over maturity stages and found that there were some significant differences in fatty acids between males and females prior to spawning but not for the post-spawning stages. They suggested that this is probably due to the presence, at stage 4 , immediately before the release of gametes, of high levels of gametes with different fatty acid composition. Triglycerides, important for embryos during early development, are the main non-polar lipids in the eggs of sea urchins (Kozhina et al. 1978; Sewell 2005; Villinski et al. 2002; Yasumasu et al. 1984) but are present at very low levels or even absent in spermatozoa where phospholipids clearly predominate (Kozhina et al. 1978; Mita et al. 1994). Triglycerides and phospholipids have usually distinctive fatty acid profiles and, for example, in the gametes of different sea urchin species, it has been shown that phospholipids have higher levels of 18:0, 20:4n-6 and 20:5n-3 than triglycerides but lower proportions of 14:0, 16:0 and 16:1n-7 (Kozhina et al. 1978; Metzman et al. 1978; Mita et al. 1994). In our study, sampling was carried out in the period of the reproductive cycle in which we knew that gametes (premature or fully developed) were present, avoiding the post-spawning or recovery stages (Martínez et al. 2003; Sánchez-España et al. 2004, personal observations). Thus, gender differences observed in the levels of 14:0, 16:0, 18:0 and 20:4n-6 could be due, at least in part, to the presence of gametes (sperm or oocytes) in the gonads. On the other hand, the higher percentages of $18: 2 n-6,18: 3 n-3$ and $18: 4 \mathrm{n}-3$ found in the female gonads of $P$. lividus and A. lixula suggest that females specifically retain these fatty acids that could be subsequently transferred to eggs; then larvae would have a source of essential fatty acids until they were able to feed by themselves. In that sense, it has been recently reported in different sea urchin species that larvae do not have specific requirements for long-chain PUFA and that they can normally develop when the diet supplies adequate amounts of $18: 2 n-6,18: 3 n-3$ and $18: 4 n-3$ (Liu et al. 2007a, b).

We identified two non-methylene-interrupted dienoic fatty acids (NMID) 20:2 $\Delta 5,11$ and 20:2 $\Delta 5,13$, in the gonads of A. lixula and P. lividus. The presence of 20 and 22 carbon NMI has been previously reported in the soft tissues of P. lividus (Serrazanetti et al. 1995) as well as in other sea urchin species (Cook et al. 2000; Liyana-Pathirana et al. 2002b; Hughes et al. 2005, 2006; Takagi et al. 1986). The exact physiological function of NMID has not been established; but because of their predominance in polar lipids, it has been suggested that they have functional and structural roles in membranes (Kraffe et al. 2004). These fatty acids are not found in the algae usually consumed by sea urchins; thus, their presence in the gonads of both sea urchins species suggests that they have been formed endogenously by $\Delta 5$ desaturation of their immediate precursors 20:1n-9 and 20:1n-7, as previously described by Zhukova (1991) in molluscs. The levels of NMID were reported to be higher in the female gonads of two limpet species when compared to the male gonads (Kawashima 2005). In our study, the two identified NMID showed also higher proportions in ovaries than in testes although differences were only significant in A. lixula and not in P. lividus. A clear relationship between the levels of 20:2 $\Delta 5,11$ and $20: 2 \Delta 5,13$ and those of their immediate precursors, 20:1n-9 and $20: 1 \mathrm{n}-7$, was not observed in the gonads of both sea urchin species since, for example, the level of 20:1n-9 was higher in the female gonads of A. lixula, lower in those of $P$. lividus from La Herradura and showed no differences with males in P. lividus from Torregorda. Thus, it seems that the synthesis of NMID does not only depend on the availability of their precursors. Furthermore, as these fatty acids are present in higher proportions in ovaries than in testes, they could play specific roles in female reproductive physiology.

On the other hand, comparing either male or female gonad fatty acids of subtidal Mediterranean P. lividus with those of the intertidal Atlantic site, we found that these were also influenced by location. The most important differences were observed in some MUFA (18:1n-7, 20:1n-11 and 20:1n-9) and in the main long-chain PUFA (20:5n-3, 22:6n-3, 20:4n-6 and 22:4n-6). Male and female gonads 
$P$. lividus collected at Torregorda showed higher levels of 18:1n-7, 20:1n-9, 20:4n-6 and 22:4n-6, whereas 20:1n-11, 20:5n-3 and 22:6n-3 were higher in the specimens collected at La Herradura.

In marine ecosystems, the two main factors that can modify tissue fatty acids are water temperature and diet. In marine invertebrates, it has been reported that when temperature decreases, there is an increase of polyunsaturated fatty acids in order to maintain the functionally optimal membrane fluidity (Sanina and Kostetsky 2002). However, it is unlikely that the differences in PUFA composition are due to temperature since we put together all data obtained from the gonads of the specimens collected during the first half year and, as earlier mentioned, water temperatures are very similar at La Herradura and Torregorda. Therefore, changes observed in gonad fatty acid composition may be related to differences in the macroalgae species consumed by $P$. lividus at both sites. This species usually feeds on brown algae and less frequently on green algae (Boudouresque and Verlaque 2007). Stypocaulon scoparia predominates at La Herradura together with other brown algae whereas at Torregorda the assemblage is a mixture of brown (mainly Dyctiota dichotoma and D. fasciola) and green algae (mainly Ulva spp.). Although we did not analyze the fatty acids of these algae species and therefore cannot establish a direct relationship with the fatty acid content of the animals, it is likely that the different algal diet has influenced animal fatty acid composition. Furthermore, although macroalgae constitute the main feeding resource of $P$. lividus, this sea urchin is an opportunistic species that can exploit other food resources such as microalgae, sponges, hydrozoa or copepods (Boudouresque and Verlaque 2007) whose occurrence could also differ between both locations. For example, the source of 20:1n-11 found in higher proportions in the gonads of the specimens collected at La Herradura, could be sponges (Nechev et al. 2004; Zimmerman et al. 1989), that are more abundant at the rocky subtidal areas of La Herradura than at the swallow ponds of Torregorda. And the source of 20:1n-9 could be copepods which it is known to be enriched in this longchain monounsaturated fatty acid (Falk-Petersen et al. 1987).

In conclusion we report, for the first time, sex differences in gonad fatty acids of the sea urchins Paracentrotus lividus and Arbacia lixula, and we speculated with the possibility that these differences were related either to specific requirements of males and females during gametogenesis and/or to differences in the fatty acid composition of the spermatozoa and oocytes present in mature testes and ovaries. Additionally, we have also found an environmental influence on gonad fatty acid composition that is probably related to differences in the available food resources.
Acknowledgments We wish to express our gratitude to Ana Sánchez-España who helped us to collect most of the samples and to extract the gonads in the laboratory.

\section{References}

Boudouresque CF, Verlaque M (2007) Ecology of Paracentrotus lividus. In: Lawrence JM (ed) Edible sea urchins: biology and ecology. Elsevier, Amsterdam, pp 243-283

Caers M, Coutteau P, Cure K, Morales V, Gajardo G, Sorgeloos P (1999) The Chilean scallop Argopecten purpuratus (Lamarck, 1819): I Fatty acid composition and lipid content of six organs. Comp Biochem Physiol 123B:89-96

Cook EJ, Bell MV, Black KD, Kelly MS (2000) Fatty acid compositions of gonadal material and diets of the sea urchin, Psammechinus miliaris: trophic and nutritional implications. J Exp Mar Biol Ecol 255:261-274

Falk-Petersen S, Sargent JR, Tande KS (1987) Lipid composition of zooplankton in relation to the sub-Arctic food web. Polar Biol $8: 115-120$

Fenaux L, Malara G, Cellario C, Charra R, Palazzoli I (1977) Evolution des constituants biochimiques des principaux compartiments de l'oursin Arbacia lixula (L.) au tours d'un cycle sexuel et effets d'un jeüne de courte durée au cours de la maturation sexuelle. J Exp Mar Biol Ecol 28:17-30

Fernández C (1997) Effect of diet on the biochemical composition of Paracentrotus lividus (Echinodermata: Echinoidea) under natural and rearing conditions (Effect of diet on biochemical composition of urchins). Comp Biochem Physiol 118A:1377-1384

Fernández C, Pergent G (1998) Effect of different formulated diets and rearing conditions on growth parameters in the sea urchin Paracentrotus lividus. J Shellfish Res 17:1571-1581

Frantzis A, Berthon JF, Maggiore F (1988) Relation trophique entre les oursin Arbacia lixula et Paracentrotus lividus (Echinoidea regularia) et le phytobenthos infralittoral superficial de la baie de Port-Cross (Var, France). Sci Rep Port-Cros Natl Park 14:81-140

Grubert MA, Dunstan GA, Ritar AJ (2004) Lipid and fatty acid composition of pre- and post-spawning blacklip (Haliotis rubra) and greenlip (Haliotis laevigata) abalone conditioned at two temperatures on a formulated feed. Aquaculture 242:297-311

Guerra-García JM, Martínez-Pita I, Pita ML (2004) Fatty acid composition of the Caprellidea (Crustacea: Amphipoda) from the strait of Gibraltar. Sci Mar 68:501-510

Hammer H, Hammer B, Watts S, Lawrence A, Lawrence J (2006) The effect of dietary protein and carbohydrate concentration on the biochemical composition and gametogenic condition of the sea urchin Lytechinus variegatus. J Exp Mar Biol Ecol 334:109-121

Hughes AD, Catarino AI, Kelly MS, Barnes DKA, Black KD (2005) Gonad fatty acids and trophic interactions of the echinoid Psammechinus miliaris. Mar Ecol Prog Ser 305:101-111

Hughes AD, Kelly MS, Barnes DKA, Catarino AI, Black KD (2006) The dual functions of sea urchin gonads are reflected in the temporal variations of their biochemistry. Mar Biol 148:789-798

Kawashima H (2005) Unusual minor nonmethylene-interrupted di-, tri-, and tetraenoic fatty acids in limpet gonads. Lipids 40:627-630

Kozhina VP, Terekhova TA, Svetashev VI (1978) Lipid composition of gametes and embryos of the sea urchin Strongylocentrotus intermedius at early stages of development. Dev Biol 62:512-517

Kraffe E, Soudant P, Marty Y (2004) Fatty acid composition of serine, ethanolamine and choline plasmalogens in some marine bivalves. Lipids 39:59-66

Lepage G, Roy CC (1987) Direct transesterification of all classes of lipids in a one-step reaction. J Lip Res 27:114-120 
Liu H, Kelly MS, Cook EJ, Black K, Orr H, Zhu JX, Dong SL (2007a) The effect of diet type on growth, fatty-acid composition of sea urchin larvae, I. Paracentrotus lividus (Lamarck, 1816) (Echinodermata). Aquaculture 264:247-262

Liu H, Kelly MS, Cook EJ, Black K, Orr H, Zhu JX, Dong SL (2007b) The effect of diet type on growth and fatty-acid composition of sea urchin larvae, II Psammechinus miliaris (Gmelin). Aquaculture 264:263-278

Liyana-Pathirana CF, Shahidi Whittick A (2002) The effect of an artificial diet on the biochemical composition of the gonads of the sea urchin (Strongylocentrotus droebachiensis). Food Chem 79:461472

Liyana-Pathirana C, Shahidi F, Whittick A, Hooper R (2002) Lipid and lipid soluble components of gonads of green sea urchin (Strongylocentrotus droebachiensis). J Food Lipids 9:105-126

Marsh AG, Watts SA (2001) Biochemical and energy requirements of gonad development. In: Lawrence JM (ed) Edible sea urchins: biology and ecology. Elsevier, Amsterdam, pp 27-42

Martínez I, García FJ, Sánchez AI, Daza JL, del Castillo F (2003) Biometric parameters and reproductive cycle of Paracentrotus livi$d u s$ (Lamarck) in three habitats of Southern Spain. In: Feral JP, David B (eds) Echinoderm research 2001. Swets and Zeitlinger, Lisse, pp 281-287

Meidel SK, Scheibling RE (1999) Effects of food type and ration on reproductive maturation and growth of the sea urchin Strongylocentrotus droebachiensis. Mar Biol 134:155-166

Metzman MS, Mastroianni A, Strauss JF (1978) Fatty acid composition of unfertilized and fertilized eggs of the sea urchin, Arbacia punctulata. Lipids 13:823-824

Mita M, Nakamura M (2001) Energy metabolism of sea urchin spermatozoa: the endogenous substrate and ultrastructural correlates. In: Jangoux M, Lawrence JM (eds) Echinoderm studies, 6th edn. Balkema, Rotterdam, pp 85-110

Mita M, Oguchi A, Kikuyama S, Namiki H, Yasumasu I, Nakamura M (1994) Comparison of sperm lipid components among four species of sea-urchin based on echinoid phylogeny. Comp Biochem Physiol 108B:417-422

Morais S, Boaventura D, Narciso L, Re P, Hawkins SJ (2003) Gonad development and fatty acid composition of Patella depressa Pennant (Gastropoda: Prosobranchia) populations with different patterns of spatial distribution, in exposed and sheltered sites. J Exp Mar Biol Ecol 294:61-80

Nechev J, Christie W, Robaina R, De Diego F, Popov S, Stefanov K (2004) Chemical composition of the sponge Hymeniacidon sanguinea from the Canary Islands. Comp Biochem Physiol 137A:365-374

Privitera D, Chiantore M, Mangialajo L, Glavi N, Kozul W, CattaneoVietti R (2008) Inter- and intraspecific competition between Paracentrotus lividus and Arbacia lixula in resource-limited barren areas. J Sea Res 60:184-192

Raymond JF, Himmelman JH, Guderley HE (2007) Biochemical content, energy composition and reproductive effort in the broadcasting sea star Asterias vulgaris over the spawning period. J Exp Mar Biol Ecol 341:32-44

Sánchez-España A, Martínez-Pita I, García F (2004) Gonadal growth and reproduction in the comercial sea urchin Paracentrotus lividus (Lamarck, 1816) (Echinodermata: Echinoidea) from Southern Spain. Hydrobiologia 519:61-72

Sanina NM, Kostetsky EY (2002) Thermotropic behaviour of major phospholipids from marine invertebrates: changes with warmacclimation and seasonal acclimatization. Comp Biochem Physiol 133B:143-153

Serrazanetti GP, Pagnucco C, Conte LS, Cattani O (1995) Hydrocarbons, sterols and fatty acids in sea urchin (Paracentrotus lividus) of the Adriatic sea. Chemosphere 30:1453-1461

Sewell MA (2005) Utilization of lipids during early development of the sea urchin Evechinus chloroticus. Mar Ecol Prog Ser 304:133-142

Takagi T, Kaneniwa M, Itabashi Y, Ackman RG (1986) Fatty acids in echinoidea: unusual cis-5-olefinic acids as distinctive lipid components in sea urchins. Lipids 21:558-565

Unuma T, Yamamoto T, Akiyama T, Shiraishi M, Ohta H (2003) Quantitative changes in yolk protein and other components in the ovary and testis of the sea urchin Pseudocentrotus depressus. J Exp Biol 206:365-372

Villinski JT, Villinski JC, Byrne M, Raff RA (2002) Convergent maternal provisioning and life-history evolution in echinoderms. Evolution 56:1764-1775

Yasumasu I, Hino A, Suzuki A, Mita M (1984) Change in the triglyceride level in sea urchin eggs and embryos during early development. Dev Growth Differ 26:525-532

Zhukova NV (1991) The pathway of the biosynthesis of non-methylene-interrupted dienoic fatty acids in molluscs. Biochem Physiol 100B:801-804

Zimmerman MP, Thomas FC, Thompson JE, Djerassi C, Streiner H, Evans E, Murphy PT (1989) The distribution of lipids and sterols in cell types from the marine sponge Pseudaxinyssa sp. Lipids $24: 210-216$ 